\title{
The Influence of Saliva pH on the Fracture Resistance of Three Complete Denture Base Acrylic Resins
}

\author{
Juliana de Sá $\left(D,{ }^{1}\right.$ Francisca Vieira $\left(\mathbb{D},{ }^{1}\right.$ Carlos Manuel Aroso $\left(\mathbb{D},{ }^{2}\right.$ Mónica Cardoso $(\mathbb{D})^{2}$ \\ José Manuel Mendes $\mathbb{D}^{2},{ }^{2}$ and António Sérgio Silva $\mathbb{D D}^{2}$ \\ ${ }^{1}$ Department of Oral Rehabilitation, Instituto Universitário de Ciências da Saúde, Gandra, Portugal \\ ${ }^{2}$ Dental Science Department, Instituto de Investigação e Formação Avançada em Ciências e Tecnologias da Saúde (IINFACTS), \\ Gandra, Portugal
}

Correspondence should be addressed to António Sérgio Silva; antonio.sergio.oliveira.silva@gmail.com

Received 26 October 2019; Revised 8 September 2020; Accepted 14 October 2020; Published 2 November 2020

Academic Editor: Alessandro Leite Cavalcanti

Copyright (C) 2020 Juliana de Sá et al. This is an open access article distributed under the Creative Commons Attribution License, which permits unrestricted use, distribution, and reproduction in any medium, provided the original work is properly cited.

\begin{abstract}
Aim and Background. The absorption of fluids by denture base materials diminishes the mechanical properties such as hardness, strength, and fatigue limit due to the plasticizing effect of water. This study aimed to evaluate the influence of oral pH on the fracture resistance of prosthetic bases made of three different heat-polymerizable acrylic resin brands: RS Vertex ${ }^{\circledR}$, Triplex Hot ${ }^{\circledR}$, and Megacryl ${ }^{\circledR}$. The strength needed to fracture the resins and the resistance to fracture each resin were evaluated. Methods. Ten prosthesis bases prepared with each brand of resin were subjected to neutral and low $\mathrm{pH}$ conditions ( $\mathrm{pH} 7$ and $\mathrm{pH} 4)$ by submerging them in artificial saliva for 30 days. After exposure, the fatigue resistance of the resins was tested using a Dental CS ${ }^{\circledR}$ Testing Machine. Statistical Analysis Test. The data sets were described quantitatively in terms of mean $(M)$ and standard deviation (SD). Shapiro-Wilk tests and unilateral analysis of variance (ANOVA) were performed and complemented by Tukey's multiple comparison tests. The effect size ( $\eta 2)$, whose cohort points followed Cohen's recommendations: 0.01 (low), 0.06 (medium), and 0.14 (high), was calculated. The results were considered significant if $p<0.05$ and marginally significant if $p<0.10$. Results. Oneway ANOVA showed that Megacryl ${ }^{\circledR}$ had the highest fracture resistance at pH 7 (52.23 Kgf), compared with Triplex Hot ${ }^{\circledR}$ $(p<0.001)$ and RS Vertex ${ }^{\circledR}(p=0.034)$. Two-way ANOVA confirmed the interaction between brand and $\mathrm{pH}(p=0.022)$, also revealing that brands comparison is significant or marginally significant, when $\mathrm{pH}$ is not considered (Megacryl ${ }^{\circledR}$ versus Triplex $\operatorname{Hot}^{\circledR}, p<0.001$, and RS Vertex ${ }^{\circledR}, p=0.058$; Triplex Hot $^{\circledR}{ }^{\circledR}$ versus RS Vertex ${ }^{\circledR}, p=0.051$ ), and pH 7 results were significantly higher $(p=0.003)$, even when brands are not considered. Hence, Megacryl ${ }^{\circledR}$ at $\mathrm{pH} 7$ was found to have the highest fracture resistance, detached from other brands and $\mathrm{pH}$ values. Conclusion. It can be concluded within the limitations of this study that there are differences in the fracture resistance among the three brands of acrylic resin. Megacryl ${ }^{\circledR}$ was found to have the highest fracture resistance, and Triplex $\operatorname{Hot}^{\circledR}$ was the lowest. The results also show that exposure to a low $\mathrm{pH}$ environment decreases the fracture resistance of the Megacryl ${ }^{\circledR}$ and RS Vertex ${ }^{\circledR}$ resins.
\end{abstract}

\section{Introduction}

Oral rehabilitation aims to restore a patient's function and aesthetics by improving phonetics, nourishment, and facial aesthetics and, consequently, achieve better social integration and increased self-esteem. The percentages of all edentulous people have declined in several countries; however, with increasing average life expectancy and aging in the Western world, it is estimated that, by 2025 , more than
$50 \%$ of the population will be more than 50 years old. Despite advancements in oral hygiene, it is likely that many of these people will need full or partial dentures to replace missing teeth $[1-3]$.

Acrylic resins, introduced by Wright in 1937, consist of polymethyl methacrylate (PMMA), which is formed by mixing a polymethyl methacrylate powder (polymer) and a methyl methacrylate liquid (monomer) (MMA). In acrylic resins, the correct powder-to-liquid ratio is important. They 
are typically mixed in a $3: 1$ ratio. There are three types of polymerization of acrylic resins: self-curing, heat-curing, and light-curing [4-7].

Heat-polymerizable resins have the following advantages: they are easy to process [4] and cost-effective and have excellent aesthetics $[4,8]$, low density, good repairability and relining [8], good dimensional stability $[4,8]$, good corrosion resistance, and low solubility in oral fluids. The disadvantages of acrylic resins include polymerization shrinkage, low tensile strength, low impact and fatigue resistance, high radiolucency, low thermal conductivity, and low flexibility (which permits fractures to occur). The low thermal conductivity of PMMA can lead to patient injury as a result of the loss of perception of cold and hot stimuli [3-12].

Due to their use in dentistry, acrylic resins based on PMMA must have the following characteristics: a natural appearance; high strength, rigidity, hardness, and dimensional stability; ease of handling; low density; accurate reproduction of surface details; absence of odor, taste, and toxic products; resistance to absorption of oral fluids; good retention of polymers, porcelain, and metals; resistance to bacterial growth; high radiopacity; ease of repair and cleaning; affordability; and good service life [3].

According to the American Dental Association, there should be no bubbles or voids in a denture base material when viewed without magnification. Porosity values above $11 \%$ have been linked to poor mechanical properties, impaired appearance, and retention of liquids and microorganisms. Porosity may weaken the prosthesis, resulting in high internal stress and making it more vulnerable to distortion and deformation. According to van Noort [3], approximately $30 \%$ of denture repairs performed in laboratories involve midline fracture, demonstrating that this is the most prevalent type of fracture in upper dentures [3].

The possibility of fracture due to low resistance to fatigue occurs because of the repetitive occurrence of stress in areas of the material with cracks that appear as a result of applied forces, especially chewing forces [5]. Fracture of a prosthesis due to impact is typically the result of some traumatic incidents, such as the prosthesis falling when the patient removes it from the mouth for cleaning. Although this may not necessarily result in an instant fracture, there is a possibility that a gap will form and continue to grow until the denture fractures. Inadequate strength of acrylic resin prostheses leads to fractures in $10 \%$ of prostheses during the first three years of use $[3,9]$.

Saliva, chewing, and diet can contribute to the degradation of acrylic resins. An immersed polymerized resin absorbs water because of the polar properties of the resin molecules, which lead to the diffusion of free monomers and other products. Salivary enzymes degrade polymers, resulting in the degradation of PMMA $[5,6,10]$.

Because water absorption influences resin alteration, resin behavior within the oral cavity can be simulated using artificial saliva. The performance of materials in the oral cavity should be evaluated using artificial saliva of known composition because natural saliva varies greatly. It is important to note that it is impossible to obtain artificial saliva that precisely reproduces the characteristics of human saliva, which is very inconsistent and unstable $[11,13]$.

One reason for this instability is that the $\mathrm{pH}$ of human saliva varies in response to numerous factors throughout the day. Ingestion of certain foods can cause salivary $\mathrm{pH}$ to change from a value considered neutral to a lower value considered acidic. Fermentation of carbohydrates by bacteria in the oral cavity leads to a decrease in $\mathrm{pH}$. Another condition that can trigger a decrease in oral $\mathrm{pH}$ levels is bulimia, in which gastric acid is eliminated through vomiting. Gastroesophageal reflux disease (GERD), one of the most prevalent digestive diseases today, can also lead to a decrease in oral $\mathrm{pH}$, as reported by several studies [14-16].

As saliva plays such an essential role in oral homeostasis, changes in salivary flow must be considered. Hyposalivation is characterized by a marked reduction in salivary flow and is usually associated with xerostomia. This can have several causes, such as diabetes mellitus and Sjögren's syndrome. Drug use is another possible cause of this condition [17-19].

The acidity of the oral environment can have numerous consequences, such as increased susceptibility to dental caries, periodontal tissue disease, dysgeusia, halitosis, and an increased incidence of oral infections. Prosthetic stomatitis can occur in patients with dental prostheses because of fungal growth. Another consequence of a decrease in oral $\mathrm{pH}$ is the constant contact of dental prosthesis acrylic resins with acidic saliva. Studies showed that this acidity can lead to degradation of acrylic resins with resulting in decreased microhardness, greater release of residual monomer, and decreased fracture resistance. Therefore, dental prostheses subject to acidic $\mathrm{pH}$ levels can be expected to be more fragile and, therefore, are more prone to fracture [20-22].

This study aimed to evaluate the influence of oral $\mathrm{pH}$ on fracture resistance in prosthetic bases made with three different brands of thermopolymerizable acrylic resin and which of the three resins was the most resistant to fracture.

\section{Materials and Methods}

2.1. Materials. Heat-polymerizable acrylic resin plates (RS Vertex ${ }^{\circledR}$, Triplex $\operatorname{Hot}^{\circledR}$, and Megacryl ${ }^{\circledR}$ ) (Table 1), artificial saliva (Fusayama-Meyer ${ }^{\circledR}$ ), a Dental CS ${ }^{\circledR}$ test machine, and a Memmert ${ }^{\circledR}$ glasshouse were used.

2.2. Sample Preparation. The samples were prepared using three different brands of heat-polymerizable acrylic resins (RS Vertex ${ }^{\circledR}$, Triplex Hot ${ }^{\circledR}$, and Megacryl ${ }^{\circledR}$ ). Ten prosthesis bases were formed using each brand, with dimensions of $60 \times 45 \mathrm{~mm}^{2}$ and $2 \mathrm{~mm}$ of height (Figures 1-3), using a standardized prefabricated model (Figure 4). Fusayama-Mayer solution of artificial saliva $(0.4 \mathrm{~g} / \mathrm{L} \mathrm{NaCl}, 0.4 \mathrm{~g} / \mathrm{L}$ $\mathrm{KCl}, 0.795 \mathrm{~g} / \mathrm{L} \mathrm{CaCl} 2.2 \mathrm{H}_{2} \mathrm{O}, 0.005 \mathrm{~g} / \mathrm{L} \mathrm{Na} \mathrm{Na}_{2} .9 \mathrm{H}_{2} \mathrm{O}, 0.69 \mathrm{~g} / \mathrm{L}$ $\mathrm{NaH}_{2} \mathrm{PO}_{4} \cdot 2 \mathrm{H}_{\mathrm{S}} \mathrm{O}$, and $1 \mathrm{~g} / \mathrm{L}$ urea) at $37 \pm 2^{\circ} \mathrm{C}$ was used. Two different $\mathrm{pH}$ values ( $\mathrm{pH} 4$ and $\mathrm{pH}$ 7) were obtained by incorporating $\mathrm{HCl}$ in the base formula. Before starting the mechanical fatigue test, all the materials under the study were immersed in artificial saliva with the two different $\mathrm{pH}$ 
TABLe 1: Acrylic resin characteristics.

\begin{tabular}{|c|c|c|c|}
\hline Brand & Compositions & Proportion & Polymerization techniques \\
\hline RS Vertex ${ }^{\circledR}$ & Powder: polymethyl methacrylate, catalyst, pigments & $1 \mathrm{~mL} / 0.95 \mathrm{~g}$ liquid (monomer) & \multirow{2}{*}{$20 \mathrm{~min}$ at $100^{\circ} \mathrm{C}$} \\
\hline Vertex-Dental B.V. & Liquid: methyl methacrylate, dimethacrylate & $2.3 \mathrm{~g}$ powder (polymer) & \\
\hline Triplex Hot ${ }^{\circledR}$ & Powder: polymethyl methacrylate, catalyst, pigments & $1 \mathrm{~mL}$ liquid (monomer) & \multirow{2}{*}{$45 \mathrm{~min}$ at $100^{\circ} \mathrm{C}$} \\
\hline Ivoclar Vivadent & Liquid: methyl methacrylate stab, dimethacrylate & $2.34 \mathrm{~g}$ powder (polymer) & \\
\hline Megacryl Hot ${ }^{\circledR}$ & Powder: polymethyl methacrylate, catalyst, pigments & $4 \mathrm{~g}$ liquid (monomer) & \multirow{2}{*}{$25-30 \mathrm{~min}$ at $98-100^{\circ} \mathrm{C}$} \\
\hline Megadental $\mathrm{GmbH}$ & Liquid: methyl methacrylate, dimethacrylate & $10 \mathrm{~g}$ powder (polymer) & \\
\hline
\end{tabular}

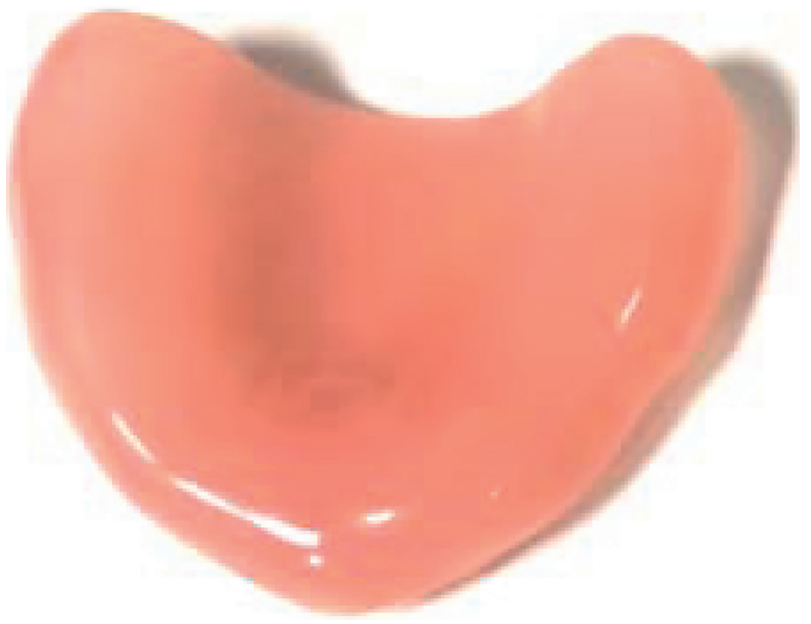

FIGURE 1: Example of an acrylic resins RS Vertex ${ }^{\circledR}$ sample.

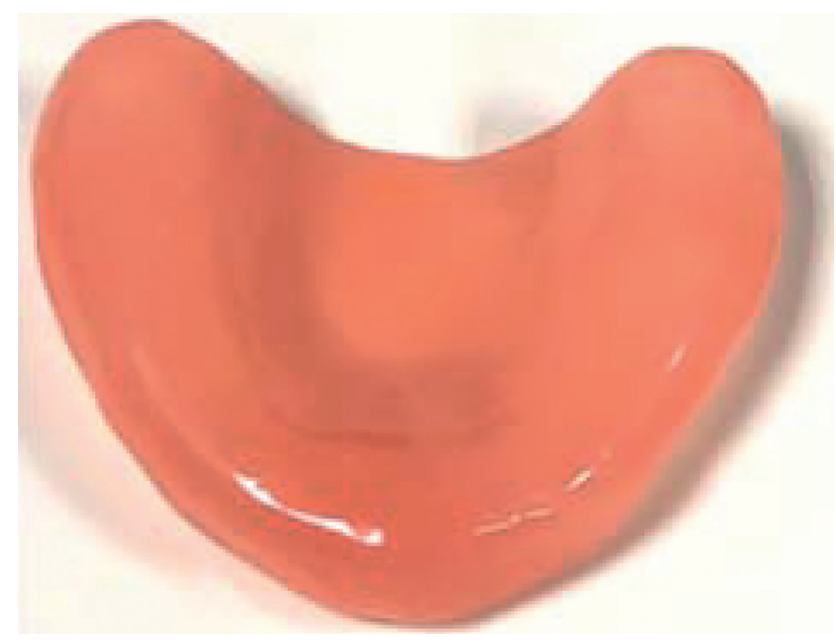

Figure 2: Example of an acrylic resins Triplex $\operatorname{Hot}^{\circledR}$ sample.

values to subject them to corrosion for 30 days. The incubator (Memmert, Germany) was heated to $37^{\circ} \mathrm{C}$ to simulate the conditions of oral temperature (Figures 5(a) and 5(b)), and the $\mathrm{pH}$ of the containers was measured 3 times per week for 30 days, using a digital $\mathrm{pH}$ meter (Ebro Electronic PTH 810, Germany). Fusayama-Mayer is well-known artificial saliva for testing products for corrosion, colorfastness, and discoloration and is used for testing a wide variety of products, including dental metal alloys. Considering a $3 \times 2$ design with 6 groups, $\alpha=0.05$, power $=0.80$, and a

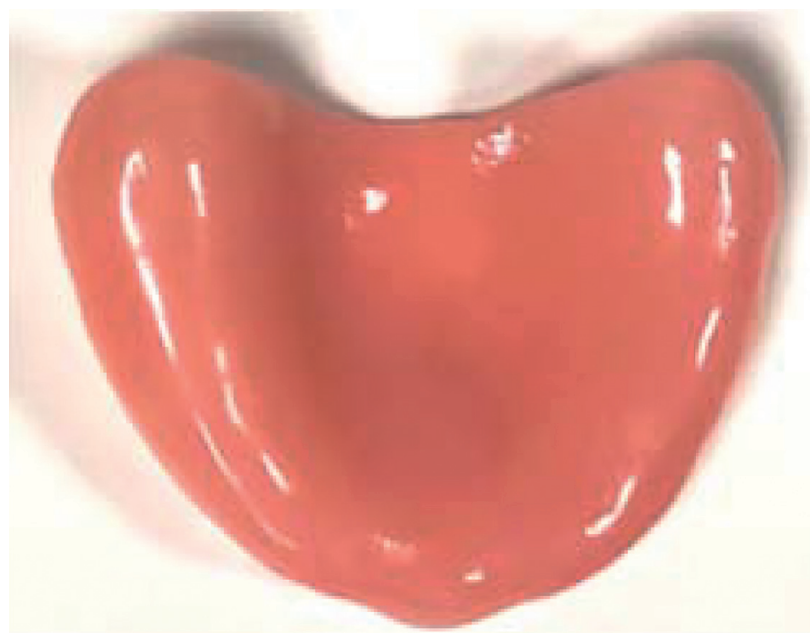

FIgURE 3: Example of an acrylic resins Megacryl ${ }^{\circledR}$ sample.

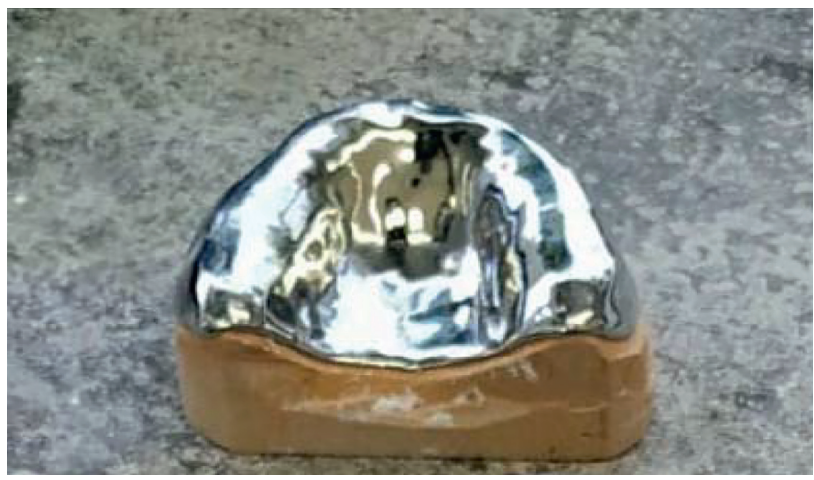

Figure 4: Prefabricated model.

maximum estimated effect size of $\eta^{2}=1.2$, and the minimum sample size was 29. Hence, 5 samples were allocated to each group. Each base was submerged in $650 \mathrm{~mL}$ of artificial saliva with a $\mathrm{pH}$ of either 4 or 7 (Figure 6). After this exposure, the fatigue resistance of the acrylic resins was tested using a Dental CS ${ }^{\circledR}$ Testing Machine (Figure 7).

$\mathrm{CS}^{\circledR}$ Dental Testing Machine is a fatigue test device built in agreement with 2006/42/CE safety of machines and the norms EN 12100-1/2, EN 954-1, EN 1037, EN 61310-1/2, EN 60204-1, EN ISSO 14121-1, and EN ISSO 13850. The basic characteristics of the machine are a motor with $150 \mathrm{~mm}$ stroke, $1600 \mathrm{~N}$ maximum force, $210 \mathrm{~mm} / \mathrm{s}$ speed, $1.06 \mathrm{~mm} / \mathrm{s}$ speed of actuator, and $3000 \mathrm{rpm}$ maximum speed forward. 


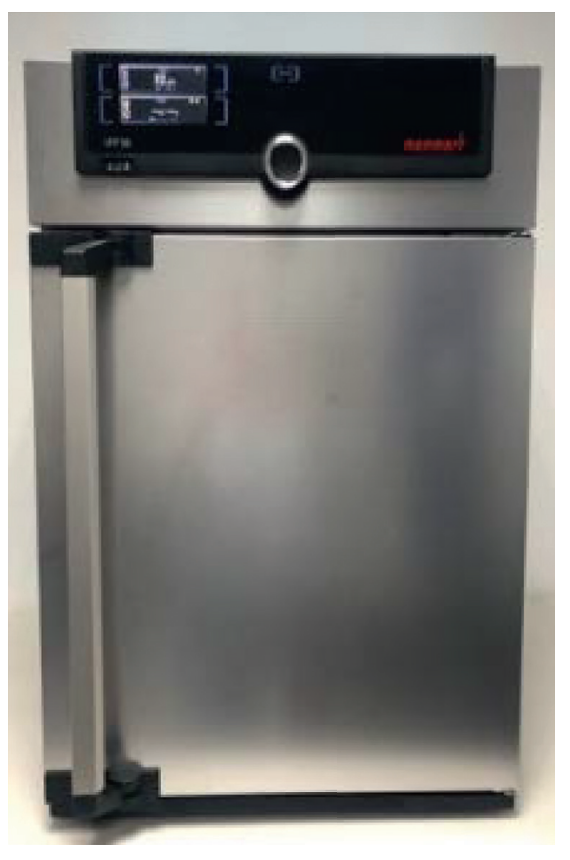

(a)

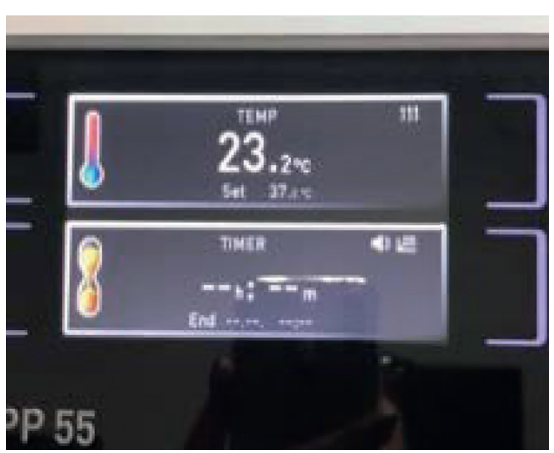

(b)

Figure 5: Memmert ${ }^{\circledR}$ glasshouse (a) at $37^{\circ} \mathrm{C}(\mathrm{b})$.

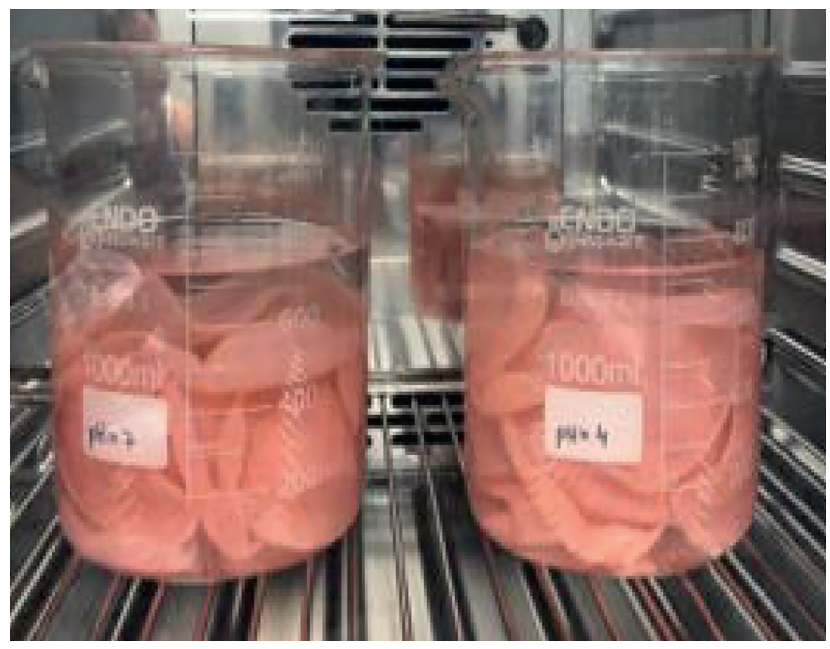

Figure 6: Prosthesis bases subjected to different $\mathrm{pH}$ values ( $\mathrm{pH} 4$ and $\mathrm{pH}$ 7).

The cell of load had a precision of $0.01 \mathrm{~N}$ and a maximum force of $1500 \mathrm{~N}$.

A point was marked at the center of the palate of each acrylic resin base (the fracture point was determined by taking the mean measure between the anteroposterior and mediolateral extremities of the denture), and the peak dislocation was measured at the point at which the acrylic fractured (Figures 8-10). The fracture force depended on the resistance of the acrylic and was detected by the load cell. A built-in program of the machine registers 4 points of strength per second. The maximum point of force, determined by the load cell where the rupture of the prosthesis occurs, was considered the fracture point. The test results were transferred to a Microsoft Office Excel ${ }^{\circledR}$ spreadsheet.
2.3. Statistical Analysis. The data were analyzed using SPSS version 22 (IBM Corporation, 2013). The data sets were described quantitatively in terms of mean $(M)$ and standard deviation (SD). Shapiro-Wilk tests were conducted to assess the normality of the distributions of the force data for each resin type and $\mathrm{pH}$ level. The results confirmed that the assumption of normality was valid in all cases $(p>0.05)$. One-way analyses of variance (ANOVAs), complemented by Tukey's multiple comparison tests, were conducted to compare the average forces applied to the point of fracture for the three brands of acrylic resin at each $\mathrm{pH}$ level. The mean forces applied to fracture the resins at both $\mathrm{pH}$ levels were compared by means of two-way ANOVAs, complemented by Tukey's multiple comparison tests and 


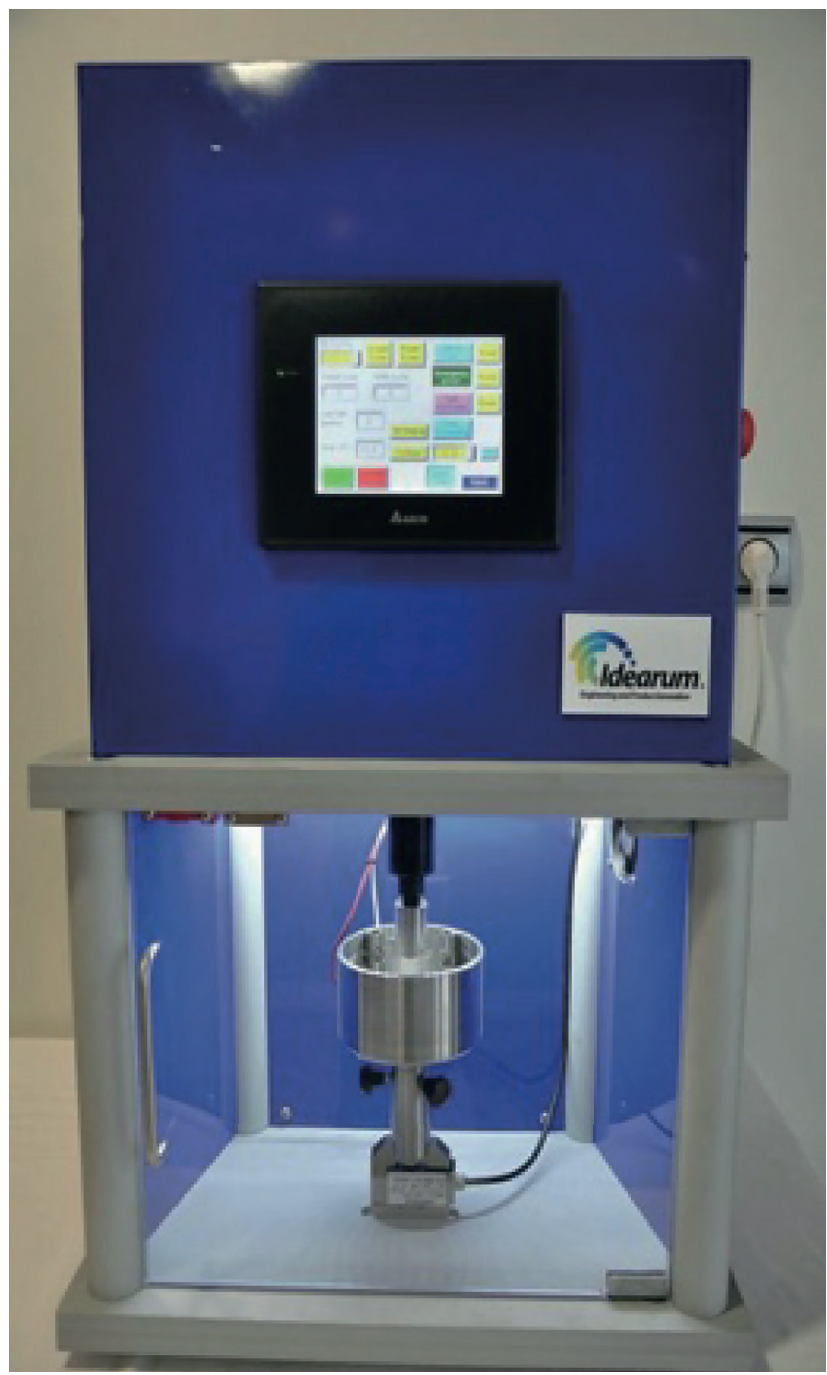

FIGURE 7: Dental $\mathrm{CS}^{\circledR}$ test machine.

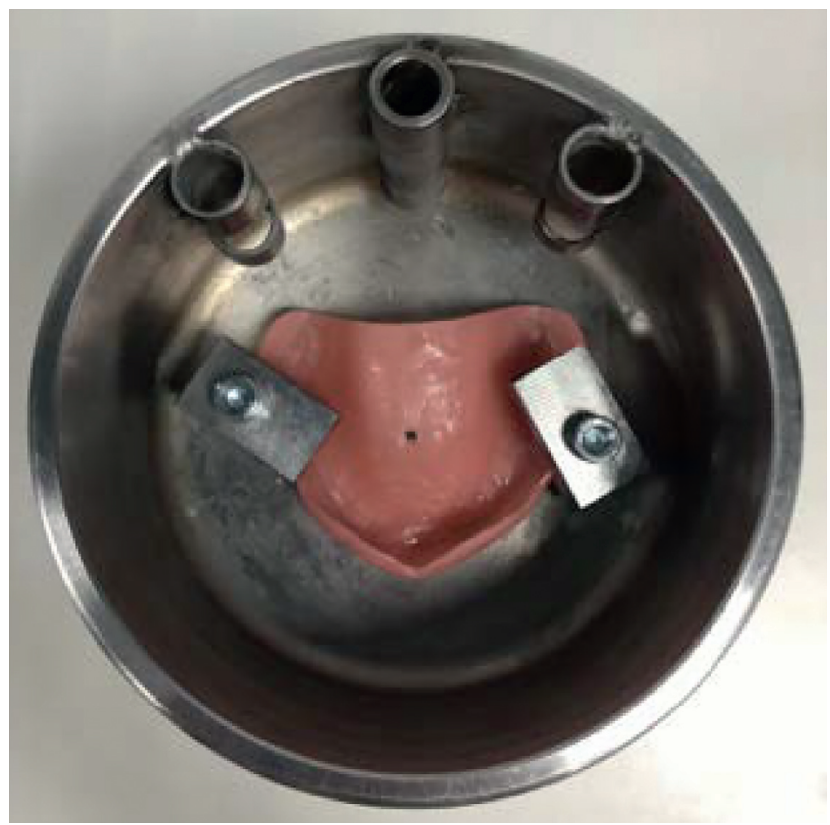

Figure 8: Prosthesis base placed to test the impact resistance. A point was marked at the center of the palate. 


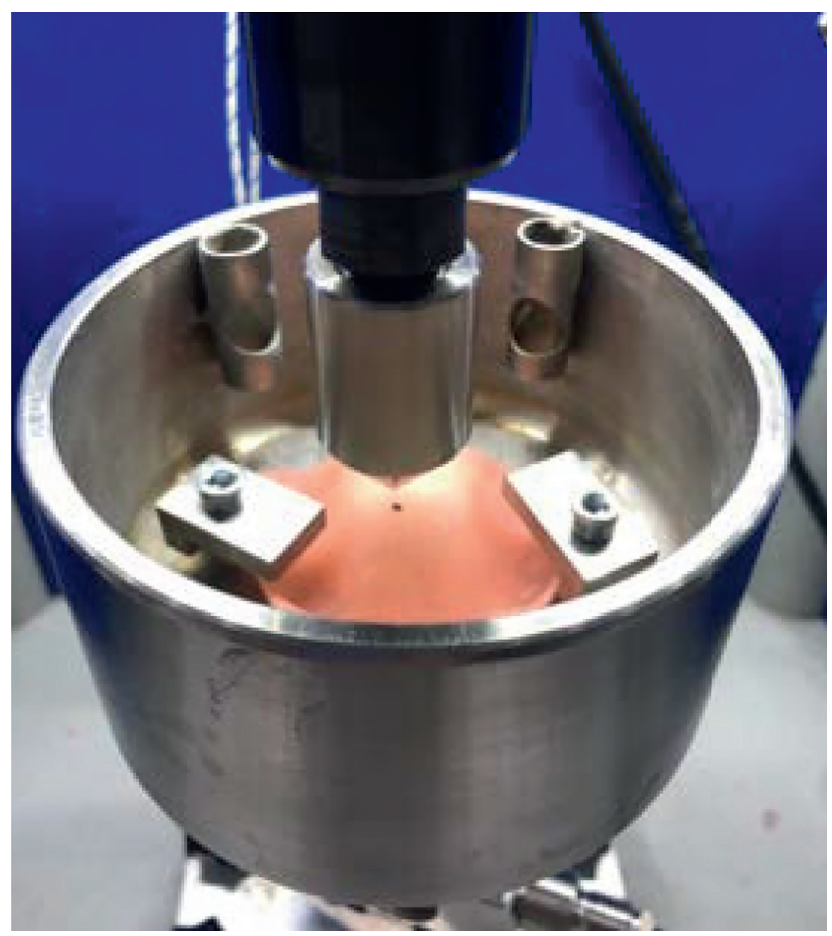

Figure 9: Peak dislocation toward prosthesis base.

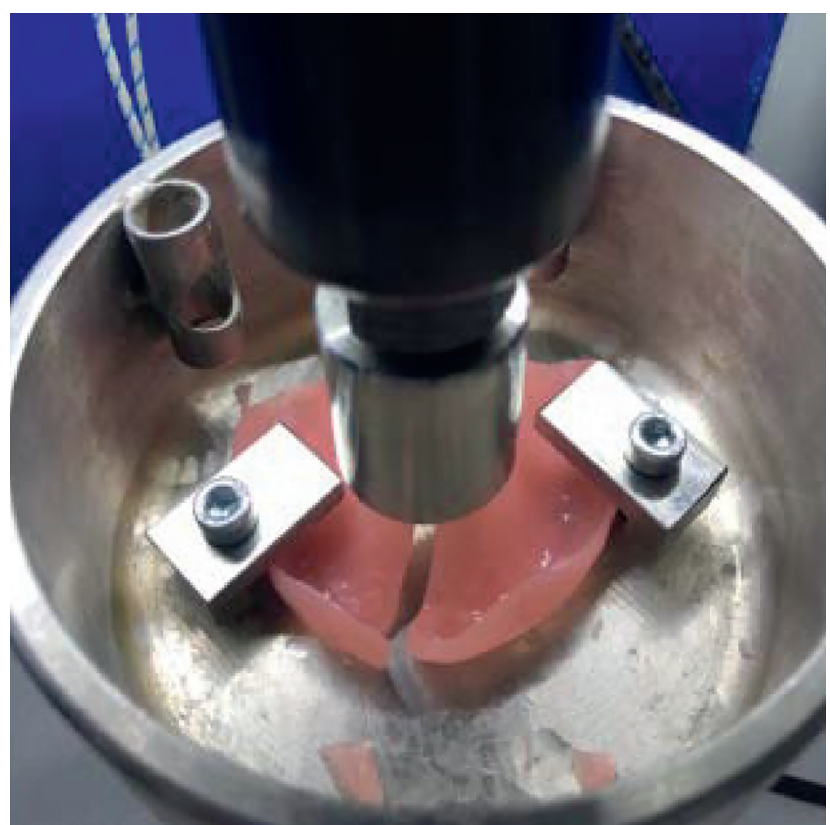

Figure 10: Prosthesis base fracture.

calculation of the effect size $\left(\eta^{2}\right)$, whose cohort points followed Cohen's [1988] recommendations: 0.01 (low), 0.06 (medium), and 0.14 (high). The results were considered significant if $p<0.05$ and marginally significant if $p<0.10$.

2.4. Qualitative Analysis of Acrylic Plates. Prior to testing, none of the plates exhibited notable porosity (Figures 11-13).
The Megacryl ${ }^{\circledR}$ subjected to $\mathrm{pH} 7$ and the Triplex $\operatorname{Hot}^{\circledR}$ subjected to $\mathrm{pH} 4$ exhibited the highest fragment loss during fracture (Figures 14 and 15, respectively) (Figure 16).

At both pH levels, RS Vertex ${ }^{\circledR}$ exhibited the lowest incidence of fragment loss (five plates without total loss) (Figures 17 and 18, respectively).

More than half of the acrylic plates (17 of 30 plates) fractured fully very close to the midline zone, regardless of whether fragments were lost. 


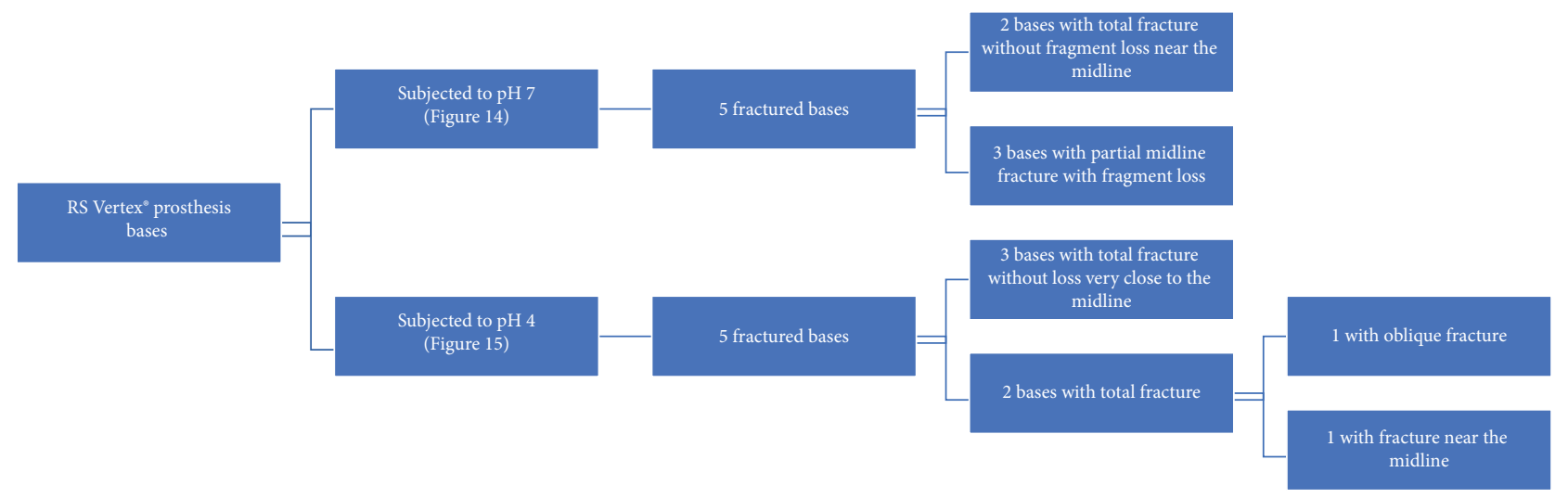

FIGURE 11: Observations concerning the fracture resistance performance of the acrylic RS Vertex ${ }^{\circledR}$ plates.

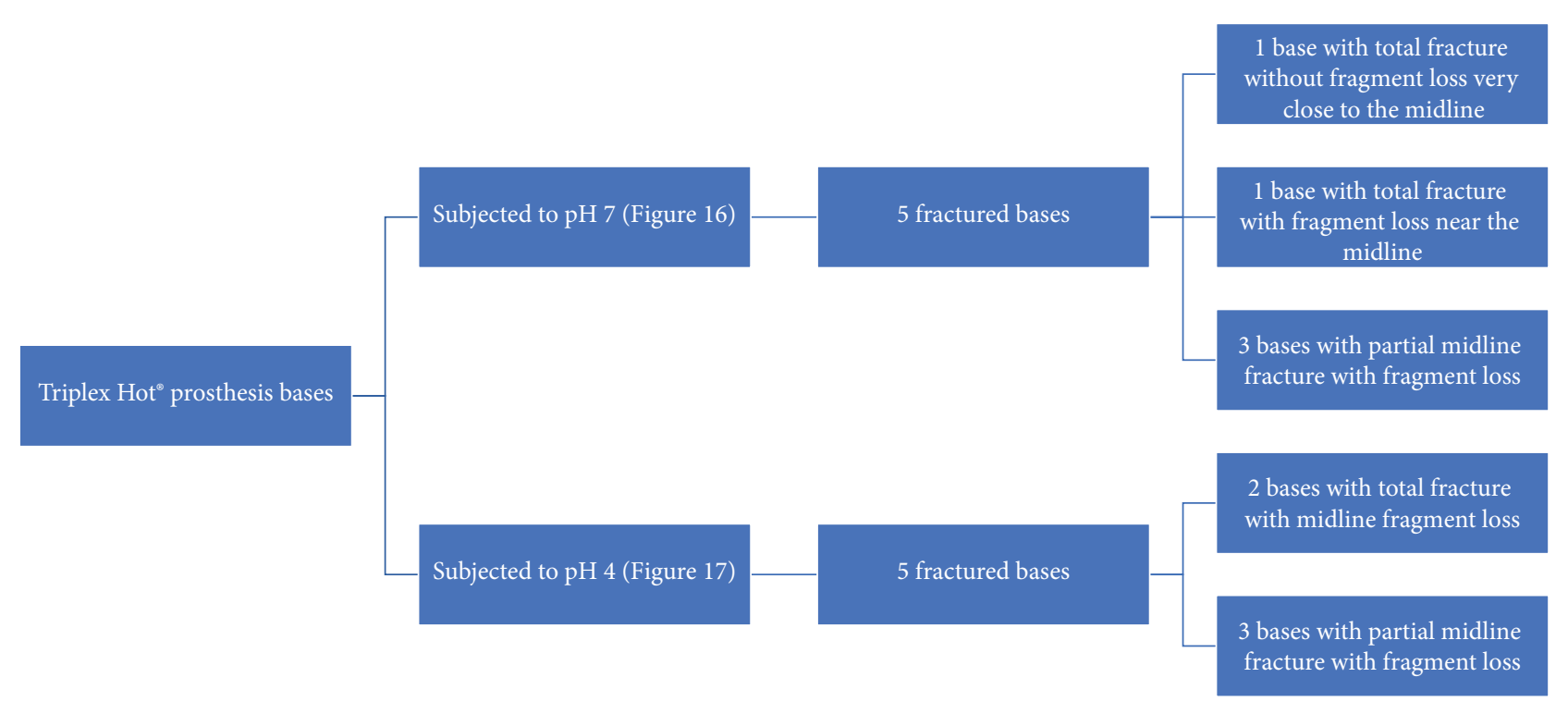

FIGURE 12: Observations concerning the fracture resistance performance of the acrylic Triplex Hot ${ }^{\circledR}$ plates.

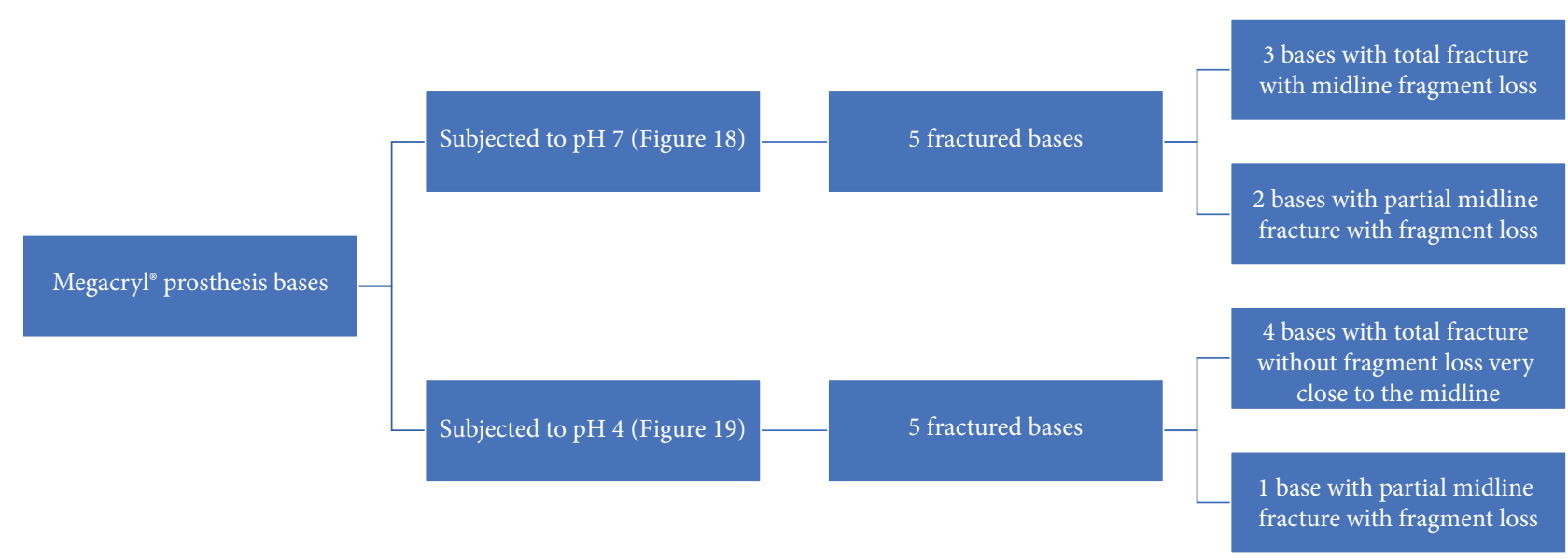

FIGURE 13: Observations concerning the fracture resistance performance of the acrylic Megacryl ${ }^{\circledR}$ plates. 


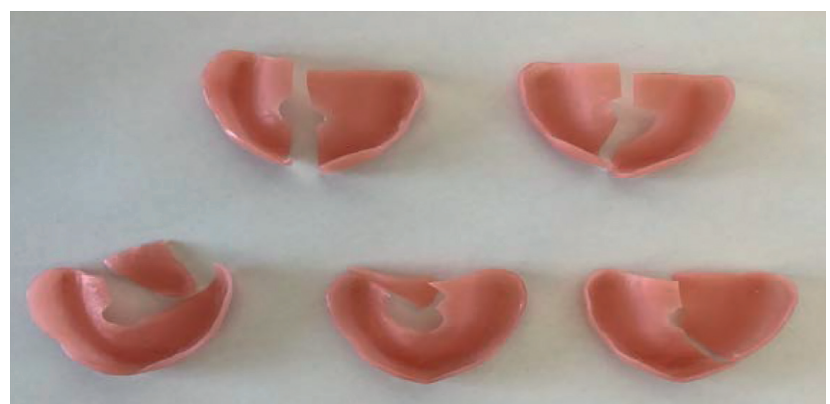

FIgURE 14: Megacryl ${ }^{\circledR}$ prosthesis bases subjected to $\mathrm{pH} 7$ after fracture.

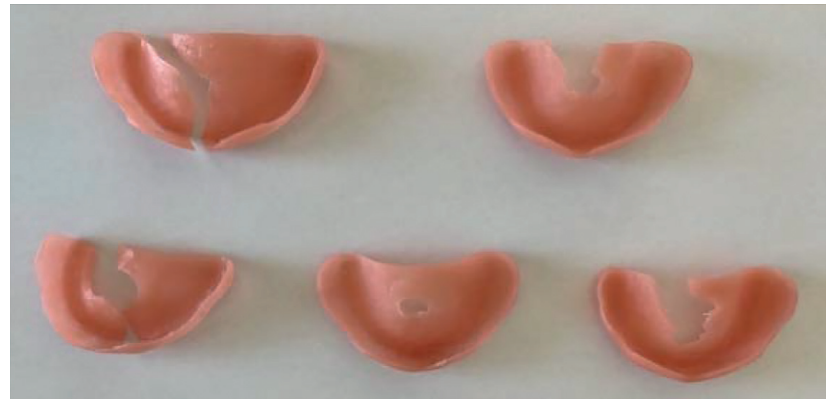

Figure 15: Triplex $\operatorname{Hot}^{\circledR}$ prosthesis bases subjected to $\mathrm{pH} 4$ after fracture.

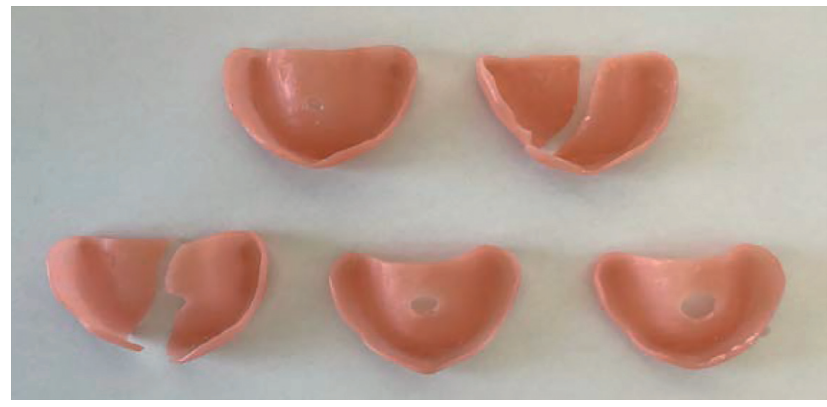

Figure 16: Triplex Hot ${ }^{\circledR}$ prosthesis bases subjected to $\mathrm{pH} 7$ after fracture.

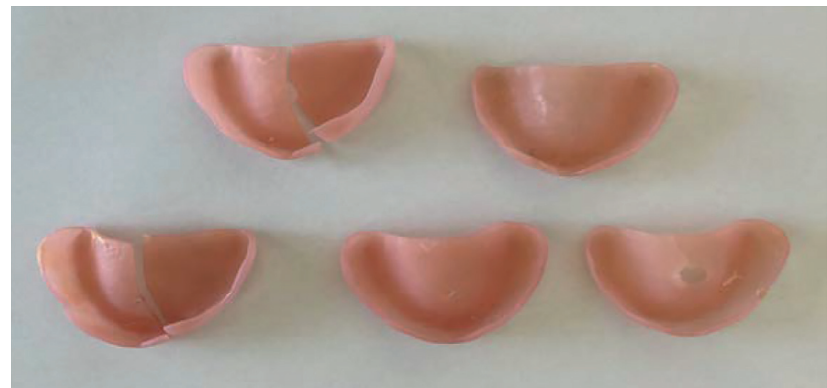

FIGURE 17: RS Vertex ${ }^{\circledR}$ prosthesis bases subjected to $\mathrm{pH} 7$ after fracture.

\section{Results}

3.1. Average Force Applied to Fracture. The Megacryl ${ }^{\circledR}$ resin had the highest fracture strength at both $\mathrm{pH} 7$ (52.23 Kgf) and pH 4 (33.29 Kgf). RS Vertex ${ }^{\circledR}$ was the next, with strength values of $40.06 \mathrm{Kgf}$ at $\mathrm{pH} 7$ and $27.94 \mathrm{Kgf}$ at $\mathrm{pH}$. The Triplex
Hot $^{\circledR}$ brand had the lowest fracture strength at both $\mathrm{pH} 7$ (23.87 Kgf) and pH 4 (26.15 Kgf) (Table 2) (Figure 19).

3.2. Time to Fracture. On average, bases subjected to $\mathrm{pH} 7$ took longer to fracture, particularly for Triplex $\mathrm{Hot}^{\circledR}$ and RS 


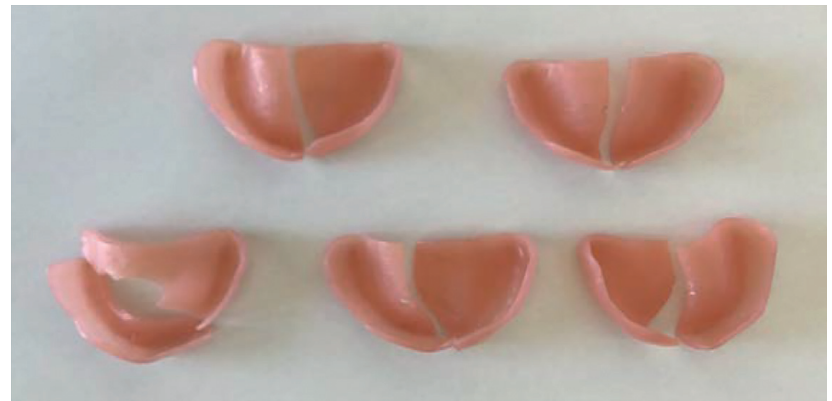

FIGURE 18: RS Vertex ${ }^{\circledR}$ prosthesis bases subjected to $\mathrm{pH} 4$ after fracture.

TABLe 2: Average force (Kgf) applied to fracture of the three brands of acrylic resin by $\mathrm{pH}$.

\begin{tabular}{lcc}
\hline Brand & $\mathrm{pH}=4(n=15)$ & $\mathrm{pH}=7(n=15)$ \\
\hline${\text { Megacryl }{ }^{\circledR}(n=10)}^{\text {Triplex Hot }^{\circledR}(n=10)}$ & $33.29(10.89)$ & $52.23(12.44)$ \\
RS Vertex $^{\circledR}(n=10)$ & $26.15(3.35)$ & $23.87(7.91)$ \\
\hline
\end{tabular}

Results are presented in $M(D P)$ format.

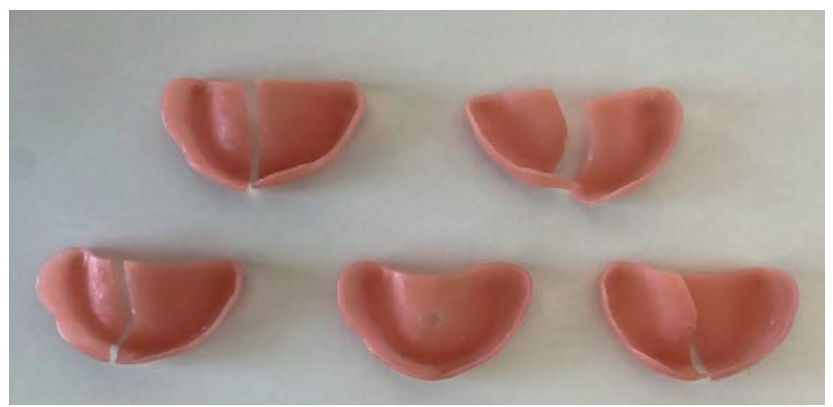

FiguRE 19: Megacryl ${ }^{\circledR}$ prosthesis bases subjected to $\mathrm{pH} 4$ after fracture.

Vertex $^{\circledR}$. For Megacryl ${ }^{\circledR}$, the times to fracture were very similar for the two pH levels (Figure 20).

\subsection{Comparison of the Average Force Applied to Fracture in the} Three Brands of Acrylic Resin Separated by Salivary pH Type Used. For the $\mathrm{pH} 4$ environment, no statistically significant differences were detected for the three considered brands: $F_{(2.12)}=1.33(p=0.301)$.

For the $\mathrm{pH} 7$ environment, significant differences between the brands were detected: $F_{(2.12)}=12.86(p<0.001)$. This was particularly true between the Triplex Hot ${ }^{\circledR}$ and Megacryl ${ }^{\circledR}$ brands $(p<0.001)$ and between the Triplex Hot ${ }^{\circledR}$ and Vertex $\operatorname{RS}^{\circledR}$ brands $(p=034)$ (Table 3$)$.

3.4. Comparison of the Average Force Applied until Fracture, considering the Interaction between the Brand and the $\mathrm{pH}$. Tables 4-6 present the results of the two-way ANOVAs conducted to compare the mean fracture force by brand and $\mathrm{pH}$ and by their interaction.

The overall results (Table 4 ) show that the average force applied to fracture varies by brand, $F_{(2.24)}=12.07(p<0.001)$, $\mathrm{pH}, \quad F_{(1.24)}=10.58 \quad(p=0.003)$, and the interaction brand $\times \mathrm{pH}, F_{(2.24)}=4.50(p=0.022)$.
Table 5 shows that, regardless of $\mathrm{pH}$, there were statistically significant differences between Megacryl ${ }^{\circledR}$ and Triplex $\operatorname{Hot}^{\circledR}(p<0.001)$ and marginally significant differences between the latter and RS $\operatorname{Vertex}^{\circledR}(p=0.051)$. Marginally significant differences were also observed between Megacryl ${ }^{\circledR}$ and the RS Vertex ${ }^{\circledR}(p=0.058)$.

Tukey's multiple comparison tests also revealed statistically relevant differences between $\mathrm{pH}$ levels, regardless of brand ( $p=0.003$ ) (Table 6).

\section{Discussion}

The study of dental materials involves observation of their characteristics and assessment of whether they benefit patients. For acrylic resin used in dental prostheses, one of the most important aspects of its performance is its fracture resistance. This study was conducted to evaluate which of three brands of the acrylic resin provides the greatest fracture resistance. Prostheses are known to experience occasional failures such as midline fractures in full dentures, tooth detachment, and other types of total or partial denture failure. Research into the causes of repair involving full and partial dentures has shown that $30 \%$ of all repairs are associated with midline fractures. Acrylic prostheses can still 


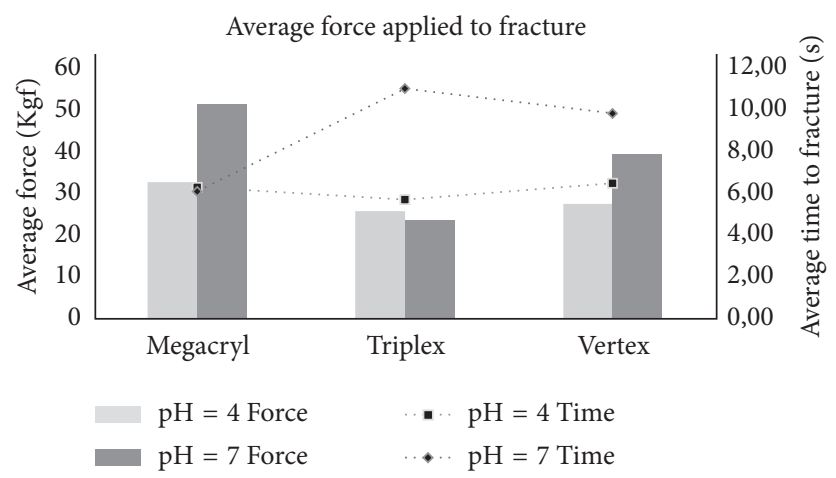

FIgURE 20: Time and average strength applied until fracture in three different acrylic resin brands by $\mathrm{pH}$.

TABle 3: One-way ANOVA test for comparison of the three $\mathrm{pH}$-separated acrylic resin brands.

\section{Tukey tests}

\begin{tabular}{lccccc}
$\mathrm{pH}$ & $F$ test & $p$ value & ${\text { Megacryl }{ }^{\circledR} \text { versus Triplex Hot }{ }^{\circledR}}$ & Megacryl $^{\circledR}$ versus RS Vertex & RS Vertex $^{\circledR}$ versus Triplex Hot $^{\circledR}$ \\
\hline $\mathrm{pH}=4$ & $F_{(2.12)}=1.33$ & $p=0.301$ & $p=0.296$ & $p=0.489$ & $p=0.919$ \\
$\mathrm{pH}=7$ & $F_{(2.12)}=12.86$ & $p<0.001^{* * *}$ & $p<0.001^{* * *}$ & $p=0.117$ & $p=0.034^{*}$ \\
\hline
\end{tabular}

${ }^{*} p<0.05 ;{ }^{* *} p<0.01 ;{ }^{* * *} p<0.001$.

TABLE 4: Global tests for brand effect, $\mathrm{pH}$, and brand $\times \mathrm{pH}$ interaction.

\begin{tabular}{lccc}
\hline Brand & $F$ test & $p$ value & Effect size $\left(\eta^{2}\right)$ \\
\hline Brand & $F_{(2.24)}=12.07$ & $p<0.0001^{* * *}$ & $\eta^{2}=0.50$ \\
$\mathrm{pH}$ & $F_{(1.24)}=10.58$ & $p=0.003^{* *}$ & $\eta^{2}=0.31$ \\
Brand $\times \mathrm{pH}$ & $F_{(2.24)}=4.50$ & $p=0.022^{*}$ & $\eta^{2}=0.27$ \\
\hline
\end{tabular}

${ }^{*} p<0.05 ;{ }^{* *} p<0.01 ;{ }^{* * *} p<0.001$.

TABle 5: Tukey multiple global comparisons between brands.

\begin{tabular}{|c|c|c|c|}
\hline Brand & Megacryl ${ }^{\circledR}$ & Triplex Hot ${ }^{\circledR}$ & RS Vertex \\
\hline Megacryl ${ }^{\circledR}$ & - & & \\
\hline Triplex $\operatorname{Hot}^{\circledR}$ & $p<0.001^{*}$ & - & \\
\hline RS Vertex ${ }^{\circledR}$ & $p=0.058^{\dagger}$ & $p=0.051^{\dagger}$ & - \\
\hline
\end{tabular}

${ }^{*} p<0.001 ;^{\dagger} p<0.10$.

TABLE 6: Tukey multiple global comparisons between $\mathrm{pH}$ valuess.

\begin{tabular}{lc}
\hline Comparisons & $p$ value \\
\hline pH 4 versus $\mathrm{pH} 7$ & $P=0.003^{* *}$ \\
\hline${ }^{* *} p<0.01$
\end{tabular}

fracture due to fatigue or shock caused by chewing, making it difficult to repair the acrylic resin. Chewing is a repetitive force that results in generalized cracks that weaken the base of the prosthesis, ultimately resulting in fracture. These types of fractures are often caused by patients who accidentally drop the prosthesis during their daily oral hygiene $[3,23,24]$. In this study, a point was marked in the central zone of each of the tested prosthesis bases to simulate this type of midline fracture.

The acrylic resin brand Megacryl ${ }^{\circledR}$ was found to have the greatest fracture strength at both $\mathrm{pH} 7$ (52.23 Kgf) and $\mathrm{pH} 4$
(33.29 Kgf). The RS Vertex ${ }^{\circledR}$ brand exhibited the next highest fracture resistance values: $40.06 \mathrm{Kgf}$ at $\mathrm{pH} 7$ and $27.94 \mathrm{Kgf}$ at $\mathrm{pH}$ 4. The Triplex $\mathrm{Hot}^{\circledR}$ brand exhibited the lowest fractures strengths at $\mathrm{pH} 7(23.87 \mathrm{Kgf})$ and $\mathrm{pH} 4$ (26.15 Kgf).

At $\mathrm{pH} 7$, there were significant differences between the Triplex $\operatorname{Hot}^{\circledR}$ and the two competitors (Megacryl ${ }^{\circledR}$ and RS Vertex $\left.{ }^{\circledR}\right)$. At $\mathrm{pH} 4$, the mean strength values up to fracture were similar for the three brands.

Another objective of this study was to assess whether oral $\mathrm{pH}$ influenced the fracture resistance of acrylic resins. It was concluded that, after exposure to an environment of $\mathrm{pH} 7$, a higher average force to fracture could be sustained. A significant interaction between the brand and the $\mathrm{pH}$ was also detected, with a higher fracture resistance being exhibited by the Megacryl ${ }^{\circledR}$ and RS Vertex ${ }^{\circledR}$ brands after $\mathrm{pH} 7$ exposure, but the same fracture as the Triplex $\operatorname{Hot}^{\circledR}$ brand, for which the results for $\mathrm{pH} 4$ and $\mathrm{pH} 7$, was very similar. 
These results suggest that acidic conditions ( $\mathrm{pH} 4$ ) may lead to decreased fracture resistance, as demonstrated by the results for the brands Megacryl ${ }^{\circledR}$ and RS Vertex ${ }^{\circledR}$. This was consistent with the results reported by Nicodemo et al. [22], who found that a low $\mathrm{pH}$ reduces the strength of acrylic resin, regardless of the processing technique. Their study demonstrated a reduction in microhardness after storage of samples in heptane and ethanol solutions with different concentrations selected to simulate the human diet. In another study, Tuna et al. demonstrated that acidic saliva conditions lead to a higher residual monomer release than neutral saliva conditions, decreasing the strength of acrylic resin.

These results reflect what happens daily with patients' acrylic prostheses because there are numerous reasons for lowered oral $\mathrm{pH}$, such as sugars consumed in the diet, which result in bacteria in the oral cavity that produce acid $[14,19]$.

Another possible cause is gastroesophageal reflux, in which there is a spontaneous movement of gastric contents from the stomach to the esophagus and a consequent reduction in salivary $\mathrm{pH}$. It has also been reported that patients with disease and/or drug-induced xerostomia and hyposalivation are more likely to have a more acidic oral $\mathrm{pH}$ because the buffering effect of saliva is diminished when it is produced in reduced amounts. This results in an increase in the number of microorganisms present in the oral cavity, which makes the medium become more acidic [25].

With respect to the time to fracture, samples of Triplex Hot ${ }^{\circledR}$ and RS Vertex ${ }^{\circledR}$ subjected to a pH 4 failed sooner than samples of Megacryl $^{\circledR}$, for which the time to fracture was the same for both $\mathrm{pH}$ values. These results reflect the decreased strength of acrylic resin under acidic $\mathrm{pH}$ conditions and, therefore, the sooner occurrence of fractures.

Overall, Megacryl ${ }^{\circledR}$ acrylic resin was the toughest and, therefore, required the greatest strength to fracture at complete fragmentation. The other two brands of acrylic resin fractured in a more homogeneous and linear manner.

This work has as main clinical objective to determine the basic characteristics of the main acrylics used in rehabilitation, to find the best material for a given rehabilitation and clinical condition of the patient.

The limitations of this study are due to the fact that it is in vitro; despite trying to mimic the oral cavity and its conditions as much as possible, there are always differences. In future investigations, it will be important to perform a longterm follow-up in vivo study.

\section{Conclusions}

Based on the results obtained using the methods and materials described in this study, the following conclusions can be drawn.

There are differences in fracture resistance among the three brands of heat-polymerizable acrylic resin analyzed in this study. The brand Megacryl® exhibited the highest fracture resistance, followed by RS Vertex ${ }^{\circledR}$ and Triplex $\operatorname{Hot}^{\circledR}$.

A low $\mathrm{pH}$ environment reduces the fracture resistance of the Megacryl ${ }^{\circledR}$ and RS Vertex ${ }^{\circledR}$ acrylic resins. The Triplex $\mathrm{Hot}^{\circledR}$ brand did not exhibit an effect of $\mathrm{pH}$ on fracture.

\section{Data Availability}

The data used to support the findings of this study are available from the corresponding author upon request.

\section{Disclosure}

The authors received no specific funding for this work.

\section{Conflicts of Interest}

The authors declare that they have no conflicts of interest.

\section{Acknowledgments}

The authors are grateful for the availability and cooperation of the Department of Dental Sciences, Cooperative for Polytechnic and University Education (Cooperativa de Ensino Superior Politécnico e Universitário-CESPU), the Advanced Institute of Research and Training in Health Sciences and Technologies (Instituto de Investigação e Formação Avançada em Ciências e Tecnologias da Saúde), Portugal, and all of the clinical directors who permitted data collection. The authors would like to thank Editage (http:// www.editage.com) for English language editing.

\section{References}

[1] A. Gupta and R. Tewari, "Evaluation and comparison of transverse and impact strength of different high strength denture base resins," Indian Journal of Dental Research, vol. 27 , no. 1 , pp. $61-65,2016$.

[2] H. Nasution, K. Kamonkhantikul, and M. Arksornnukit, "Pressure transmission area and maximum pressure transmission of different thermoplastic resin denture base materials under impact load," Journal of Prosthodontic Research, vol. 62, no. 1, pp. 44-49, 2017.

[3] R. Van Noort, Introdução Aos Materiais Dentários, Elsevier, Amsterdam, Netherlands, 3rd edition, 2010.

[4] J. Jacob, G. Shivaputrappa, and S. Ila, "Flexural strength of heat-polymerized polymethyl methacrylate denture resin reinforced sswith glass, aramid, or nylon fibers," The Journal of Prosthetic Dentistry, vol. 86, no. 4, pp. 4-7, 2001.

[5] A. F. Bettencourt, C. B. Neves, M. S. Almeida et al., "Biodegradation of acrylic based resins: a review," Dental Materials, vol. 6, pp. 171-180, 2010.

[6] R. Gautam, R. D. Singh, V. P. Sharma, R. Siddhartha, P. Chand, and R. Kumar, "Biocompatibility of polymethylmethacrylate resins used in dentistry," Journal of Biomedical Materials Research Part B: Applied Biomaterials, vol. 100, no. 5, pp. 1444-1450, 2012.

[7] S. H. Altintas, I. Yondem, O. Tak, and A. Usumez, "Temperature rise during polymerization of three different provisional materials," Clinical Oral Investigations, vol. 12, no. 3, pp. 283-286, 2008.

[8] C. Nair, B. Rao, M. C. Sajjan et al., "Manipulation of heatcure acrylic resin," Indian Dentist Research and Review, vol. 18, pp. 21-25, 2018.

[9] D. Camacho, T. Svidzinski, M. Furlaneto, M. Lopes, and G. Corrêa, "Acrylic resins for dental use based polymethylmethacrylate," Brazilian Journal of Surgery and Clinical Research, vol. 6, pp. 63-72, 2014. 
[10] M. P. Neisser and K. A. Olivieri, "Evaluation of the impact resistance and hardness of thermally activated acrylic resins for the base of complete dentures," PGR-Pós-Grad Ver, vol. 4, no. 2, pp. 35-42, 2001.

[11] M. Y. Maekawa and E. S. Uemura, "Study of the effect of artificial saliva on the flexural strength of acrylic resins for prosthetic bases," Revista de Odontologia da Universidade Cidade de São Paulo, vol. 18, no. 2, pp. 161-166, 2006.

[12] H.-H. Lee, J.-H. Lee, T.-H. Yang et al., "Evaluation of the flexural mechanical properties of various thermoplastic denture base polymers," Dental Materials Journal, vol. 37, no. 6, pp. 950-956, 2018.

[13] G. M. O. D. Queiroz, L. F. Silva, J. T. L. Ferreira, J. A. D. C. P. Gomes, and L. Sathler, "Electrochemical behavior and $\mathrm{pH}$ stability of artificial salivas for corrosion tests," Brazilian Oral Research, vol. 21, no. 3, pp. 209-215, 2007.

[14] A. Lussi, T. Jaeggi, and D. Zero, "The role of diet in the aetiology of dental erosion," Caries Research, vol. 38, no. 1, pp. 34-44, 2004.

[15] D. Popoff, T. Santa-Rosa, A. Paula et al., "Bulimia: oral manifestations and dental care," RGO-Rev Gaúcha Odontol, vol. 58, no. 3, pp. 381-385, 2010.

[16] C. A. Eckley and H. O. Costa, "Estudo comparativo do pH e do volume salivar em indivíduos com laringofaringite crônica por doença do refluxo gastroesofágica antes e após o tratamento," Revista Brasileira de Otorrinolaringologia, vol. 72, no. 1, pp. 55-60, 2006.

[17] I. Silva, A. Raiza, A. Chagas, A. Junior et al., "Hyposalivation. Etiology, diagnosis, and treatment," Revista Bahiana de Odontologia, vol. 7, no. 2, pp. 140-146, 2016.

[18] R. S. Medeiros, A. C. Albuquerque, A. B. Leite, A. Lima, K. Barros, and D. F. Silva, "Possible causes of hyposalivation in patients using removable dental prostheses," Revista Saúde e Ciência, vol. 4, no. 3, pp. 70-83, 2015.

[19] C. Assaf, A. Valdivia, P. Soares et al., "Dental erosion: diagnosis and treatment options," Revista de Odontologia da UNESP, vol. 37, no. 3, pp. 235-242, 2008.

[20] M. H. Figueiral, A. M. Azul, P. Fonseca, E. Pinto, and F. M. Branco, "Influence of saliva on prosthetic stomatitis. Revista portuguesa de Estomatologia," Medicina Dentária e Cirurgia Maxilofacial, vol. 47, no. 4, pp. 197-202, 2006.

[21] E. B. Tuna, B. G. Rohlig, E. Sancakli, G. Evlioglu, and K. Gencay, "Influence of acrylic resin polymerization methods on residual monomer release," The Journal of Contemporary Dental Practice, vol. 14, no. 2, pp. 259-264, 2013.

[22] C. Nicodemo, C. Rezende, R. Moretti-Neto, and J. Rubo, "Micro-hardness of acrylic resin utilized for provisional crowns: effect of different polymerization techniques and $\mathrm{pH}$ cycling," Brazilian Dental Science, vol. 16, no. 2, pp. 44-50, 2013.

[23] H. Agha, R. Flinton, and T. Vaidyanathan, "Optimization of fracture resistance and stiffness of heat-polymerized high impact acrylic resin with localized E-glass FiBER FORCE reinforcement at different stress points," Journal of Prosthodontics, vol. 8, pp. 1-9, 2016.

[24] P. Cevik and A. Z. Yildirim-Bicer, "The effect of silica and prepolymer nanoparticles on the mechanical properties of denture base acrylic resin," Journal of Prosthodontics, vol. 9, pp. 1-8, 2016.

[25] R. Figuerôa, B. Conterno, C. Arrais, C. Sugio, V. M. Urban, and K. H. Neppelenbroek, "Porosity, water sorption and solubility of denture base acrylic resins polymerized conventionally or in microwave," Journal of Applied Oral Science, vol. 26, pp. 1-7, 2018. 